„Analecta Cracoviensia” 52 (2020), s. 7-28

DOI: https://doi.org/10.15633/acr.4043

Andrzej Duk OFM

https://orcid.org/oooo-0002-0061-2299

Uniwersytet Papieski Jana Pawła II w Krakowie

\title{
O wątpliwych podstawach i metodologii humanistów postmodernistycznych
}

Trudno nie zgodzić się ze stwierdzeniem, że czasy współczesne mocno naznaczone są piętnem myślenia postmodernistycznego. Widać, że wiele zjawisk, nazwijmy je społeczno-humanistycznych, ma swoje korzenie w tym typie myślenia, bądź też ów sposób myślenia staje się dla tych zjawisk silnym zapleczem i wsparciem intelektualnym. Chodzi m.in. o takie współczesne i współcześnie rozumiane zagadnienia, jak: gender studies ${ }^{1}$, feminizm, psychoanaliza, egzystencjalizm, dekonstrukcja czy obecne w środowiskach pisarzy nowe

1 Studia podyplomowe z gender studies możliwe są już w Polsce w kilku ośrodkach naukowych, w tym w Polskiej Akademii Nauk, zob. https://www.kongreskobiet.pl/pl-PL/news/show/gender_ studies_w_polsce (24.02.2014). Jak czytamy na ww. stronie: „Pierwotnie były to tylko women's studies, obecnie również men's studies. Głównym obszarem badań jest tu społeczno-kulturowa tożsamość płciowa, normy kobiecości i męskości, a także, będące konsekwencją tych procesów, społeczne role i funkcje pełnione przez jednostkę. W kręgu zainteresowań gender studies znajdują się również badania nad seksualnością oraz nienormatywnością płciową (zjawiska transseksualizmu, transgenderyzmu i androgynii). Problematyka płci kulturowej ujmowana jest interdyscyplinarnie. Studia gender są realizowane w obrębie wielu dyscyplin akademickich, m.in. w filozofii, historii, socjologii, psychologii, antropologii kultury, literaturoznawstwie, historii sztuki, ekonomii i in. Teoretycy gender studies przyjmują założenie, że wszystkie aspekty ludzkiego życia uwarunkowane są konsekwencjami obowiązywania społecznych i kulturowych norm płci”. Zaś na Uniwersytecie Wiedeńskim można uzyskać $\mathrm{z}$ gender studies nawet stopień magisterski, zob. https://slw.univie. ac.at/studieren/masterstudien/gender-studies-master/ (2 lata po studiach licencjackich). Na uwagę zasługuje także fakt bardzo negatywnej oceny filozofii gender, zob. np. wywiad z ks. Dariuszem Oko, Na czym polega wielkie kłamstwo genderyzmu? Ten wywiad po porostu trzeba przeczytać!, https:// 
teorie literackie bądź semiotyczne. Mówiąc postmodernizm mamy na myśli: „...(łac. post - po, poza; modernus - nowoczesny, współczesny) - nurt myślowy tradycji idealizmu następujący "po» modernizmie (racjonalizmie), współczesna odmiana irracjonalizmu filozoficznego"².

Jean François Lyotard, uważany za papieża postmodernizmu twierdzi, że nie sprawdziła się, tj. nie okazała się adekwatna do rzeczywistości (prawdziwa) żadna $\mathrm{z}$ dotychczasowych metanarracji opisujących człowieka, świat i zjawiska, które w nich zachodzą (np. hermeneutyka znaczenia, dialektyka ducha, emancypacja podmiotu racjonalnego itd.) $)^{3}$. A to dlatego, że wszystkie one mają swoje źródło w oświeceniowym racjonalizmie, który pragnął każdą treść oraz zjawisko opisać i zamknąć zarazem w powszechne, zawsze obowiązujące ramy poznania intelektualnego. Tymczasem takie zamknięcie okazuje się po prostu niewłaściwe, a nawet niemożliwe. Nauki szczegółowe, badając wyodrębniony wycinek rzeczywistości, i tak odwołują się do narracji pozanaukowych, pragnąc uprawomocnić wyniki swoich badań ${ }^{4}$. Zamiast powszechników bardziej rzuca się w oczy i przemawia do świadomości coś zupełnie innego: różnorodność (pluralizm), dekonstrukcja, a nawet nieobecność (nieobecne/nie do opisania „unpresentable”), która w jego myśli nabiera cech pozytywnych treściowo. Okazuje się bowiem, że język który opisuje rzeczywistość i którym się posługujemy, potrafi zarówno wiele powiedzieć i wyjaśnić, ale i jednocześnie ograniczyć - niech mi będzie wolno napisać - wolność jednostki, która wyrażając siebie, pragnie ukazać coś ważnego i prawdziwego, czego nie dało się treściowo zawrzeć w żadnym znanym dotychczas ogólnym słowie czy idei. Nie powinno być zatem „reżimu jednej gry językowej”, jak mawiał francuski filozof, ale wielość wszelkich opinii i stanowisk, także w odniesieniu do moralności5. Przyczyni się to do budowania coraz lepszego, tj. bardziej różnorodnego i sprawiedliwego świata, w którym nikt nie będzie czuł się

niezalezna.pl/281208-na-czym-polega-wielkie-klamstwo-genderyzmu-ten-wywiad-po-prostutrzeba-przeczytac (24.07.2019).

2 Postmodernizm, http://www.ptta.pl/pef/pdf/p/postmodernizm.pdf, s. 1.

3 Zob. J.-F. Lyotard, The postmodern condition: a report on knowledge, transl. G. Bennington and B. Massumi; forew. F. Jameson, Minneapolis 1993, s. XXIII-XXIV. Tłumaczenie polskie: Kondycja ponowoczesna: raport o stanie wiedzy, przeł. M. Kowalska, J. Migasiński, Warszawa 1997.

4 Por. Jean François Lyotard, https://plato.stanford.edu/entries/lyotard/\#JustLighPostCond (21.09.2018).

Zob. J.-F. Lyotard, J.-L. Thébaud, Just Gaming, University Of Minnesota Press 1985, s. 36-47 (Theory and History of Literature, 20). 
wykluczony ${ }^{6}$. Tak widziana wolność jednostki jest tu tożsama z pojęciem doskonałego, nowego świata i nowego człowieka. Dopiero taka filozofia ${ }^{7}$ pokonuje „sztywny testament oświecenia”, stając się - wreszcie! - najbardziej odpowiednią, bo stricte humanistyczną ${ }^{8}$.

Czy jednak - rzeczywiście - postmodernistyczni humaniści są w stanie zupełnie pozostawić na boku intelektualne piętno oświecenia? ${ }^{9}$ Wydaje się, a nawet są na to liczne dowody, że nie. Nie chodzi o to, by jakoś gloryfikować oświeceniowy sposób myślenia lub wskazywać w tym miejscu na każdą wypowiedź postracjonalnego (postmodernistycznego / ponowoczesnego) intelektualisty świadczącą o ewentualne świadomym, lub nie, zamiłowaniu do owego racjonalizmu, co byłoby nie lada wyczynem, ale dużo bardziej o ogólny fakt, iż ci właśnie myśliciele jakoś potrzebowali i wciąż potrzebują pewnych racjonalnych, tj. powszechnych, jasnych, rozpoznawanych i usystematyzowanych treści ${ }^{10}$. Można dodać trochę przekornie: o ile całkowita rezygnacja $\mathrm{z}$ oświeceniowego racjonalizmu wychodzi im dosyć słabo, o tyle mieszanie filozoficznego racjonalizmu z ideologią oświeceniową postulującą walkę z religią oraz

${ }^{6}$ Pojęcie wykluczenia jest jednym z bardziej charakterystycznych dla postmodernistycznych humanistów, zob. np. J. Kristeva, J. Vanier, (Bez)sens słabości: dialog wiary z niewiarq̨ o wykluczeniu, przeł. K. i P. Wierzchosławscy, Poznań 2012.

7 Zob. np. A. Sokal, J. Bricmont, Modne bzdury: o nadużywaniu pojęć z zakresu nauk ścisłych przez postmodernistycznych intelektualistów, przeł. P. Amsterdamski, Warszawa 2004. Na s. 15 ww. autorzy stwierdzają: „... .liczni przedstawiciele humanistyki i nauk społecznych przyjęli filozofię, którą z braku lepszego określenia będziemy nazywać «postmodernizmem»: to stanowisko intelektualne charakteryzuje się mniej lub bardziej jawnym odrzuceniem racjonalistycznej tradycji Oświecenia, teoretycznymi dyskursami niepodatnymi na żadne sprawdziany empiryczne oraz poznawczym i kulturowym relatywizmem, zgodnie z którym nauki ścisłe są tylko «narracją» i «mitem», czy też jednym z wielu społecznych konstruktów”. Można zatem pokusić się o stwierdzenie, że tak pojmowana „wiedza” staje się powoli ideologią.

8 Zob. J.-F. Lyotard, The postmodern condition..., dz. cyt., s. 73-82.

9 Na marginesie wypada zaznaczyć, że chwilowo pominąć trzeba tzw. aspekt dogmatyczny wypływający z owego racjonalizmu, o którym jeszcze będzie mowa.

${ }^{10}$ Trudno jest postawić ostrą granicę pomiędzy terminami „racjonalizm” i „racjonalizm oświeceniowy”. Wydaje się, iż ten „oświeceniowy”, według niektórych, w sposób wyjątkowy podkreśla wartość i siłę rozumu oraz racjonalnych metod postępowania. Postmodernistyczni humaniści są przekonani, iż dotychczasowy rozwój myśli i wypływające z niego problemy współczesnego świata należy pokonać innym rodzajem racjonalności niż „dziedzictwo Oświecenia”. Otwiera to dla nich drogę do irracjonalizmu (zob. np. Nietzsche, Schopenhauer) filozoficznego. W niniejszym tekście pojęcia „racjonalizm” i „racjonalizm oświeceniowy” będą stosowane zamiennie, bez - mam nadzieję - ujmy dla klarowności całego wywodu. 
zastanym porządkiem społeczno-politycznym ${ }^{11}$ ma się $\mathrm{w}$ ich dociekaniach nadzwyczaj dobrze ${ }^{12}$.

Mówiąc bardziej precyzyjnie, niniejsza praca nie ma zamiaru wskazywać dokładnie wszystkich wątpliwych źródeł postracjonalnego myślenia i jego metod, jak mówi o tym zapewne zbyt jednoznacznie dla niejednego czytelnika jej tytuł. Chodzi raczej o mocną sugestię, graniczącą z głębokim przekonaniem, że nawet postmoderniści - zachowując metodologiczną specyfikę własnego rozumowania, do czego oczywiście mają prawo - potrzebują i poszukują zarazem czegoś trwałego, jakiejś podstawy, do której można $\mathrm{z}$ mocną dozą obiektywnej pewności odnieść swoje wywody. O ile, jak sami twierdzą, np. język zaciemnia i ogranicza pewne treści, o tyle, można dodać, że wszelkie wyrażanie tego, co nieobecne czy różnorodne, i tak wymaga pewnego określonego i powszechnie zrozumiałego znaku. Dlatego też rysem charakterystycznym dla wielu z nich będzie poszukiwanie takiego znaku w terminach właściwych dla nauk ścisłych, w ich metodach badawczych oraz psychoanalizie, której nadawać będą znamiona nauki jasnej, pewnej i ogólnie akceptowanej.

Nie ulega jednak wątpliwości, że zawsze w nauce, filozofii oraz zwykłej interpersonalnej komunikacji - wszak żyjemy po kartezjańskim cogito - nieuchronna jest tendencja do realizowania jakieś formy oświeceniowego racjonalizmu. On naprawdę systematyzuje myślenie i jest niezbędny w klarownej (jasnej, wyraźniej, logicznej) wymianie myśli między ludźmi. Po cóż więc, niejako na siłę, uciekać od owego dziedzictwa lub twierdzić, że robi się coś zupełnie innego, jak czynią to postracjonalni humaniści? A może chodzi im o pokazanie, że wszelka nauka ścisła jest tak naprawdę tylko mitem i narracją albo społecznym konstruktem - jak było to przed chwilą mówione - ludzkiego, zarażonego oświeceniowym sposobem uchwytywania rzeczywistości, umysłu, który w końcu trzeba oczyścić dla dobra ludzkości?

Chciałbym wyrazić także osobiste pragnienie, by ten tekst stał się niewielkim choćby przyczynkiem do refleksji nad poddanym krytyce stylem myślenia, ale

${ }^{11}$ Por. Racjonalizm, http://www.ptta.pl/pef/pdf/r/racjonalizm.pdf, s. 1.

${ }_{12} \mathrm{~Np}$. Andrzej Nowak twierdzi, iż Daniel Dennett, jeden z ważniejszych dziś przedstawicieli postmodernizmu, głoszący tezę o naturalnym pochodzeniu religii, atakuje religię i ludzi wierzących, wygłaszając swoje postulaty, mówiąc delikatnie, w sposób wykraczający poza ramy ogólnie przyjętego dyskursu akademickiego. Zob. A. Nowak, Przeciwko „filozofii” pogardy i nienawiści, https://wpolityce.pl/spoleczenstwo/363571-przeciwko-filozofii-pogardy-i-nienawisci (22.10.2017); zob. także: D. Dennett, Odczarowanie. Religia jako zjawisko naturalne, przeł. B. Stanosz, Warszawa 2008; D. Dennett, Dźwignie wyobraźni i inne narzędzia myślenia, przeł. Ł. Kurek, Kraków 2015. 
również intelektualną tęsknotą za tym, co naprawdę solidne, nieprzemijające i zapewne także obiektywnie obecne, pomimo nieobecności.

\section{A. Racjonalizm}

Nie da się jednoznacznie zdefiniować pojęcia racjonalizmu. To raczej, mówiąc językiem Wittgensteina, „pojęcie rodzinne”, z którego wypływają różne jego interpretacje. Dużo łatwiej przychodzi opisać je na zasadzie przeciwieństwa do najbardziej opozycyjnych względem niego terminów, takich jak: empiryzm, intuicjonizm, irracjonalizm ${ }^{13}$.

Aby lepiej zobaczyć, czym jest racjonalizm, wypada spojrzeć na jego postać przez pryzmat sześciu charakterystycznych zagadnień dla poznania jako takiego. Są to, za Tatarkiewiczem: natura poznania i jego początek, pochodzenie, metoda, zakres i ważność ${ }^{14}$. W każdym z tych zagadnień rozum, rozumność, poznanie intelektualne zajmują pierwszoplanowe miejsce. Władysław Stróżewski próbuje zaś zgłębić istotę racjonalizmu, analizując pojęcie ratio, od którego to słowo pochodzi. Zauważa, że z owym pojęciem (ratio) wiążą się takie znaczenia, jak: racja, rozum, wykaz, rachunek, zasada, pogląd, sprawa, interes, dowód, zawód, zakres, powód, wiedza, wnioskowanie, nauka, teoria, idea, istota, słuszność, kategoria, argument, władza myślenia itp. Reasumując, można powiedzieć, że racjonalistom chodzi zarówno o wskazanie solidnych źródeł dla refleksji intelektualnej, jasnego i przekazywalnego języka swoich twierdzeń, jak i o precyzyjną metodę badawczą. Trudno nie zauważyć także, iż z tak opisanym pojęciem racjonalności wiąże się ściśle pojęcie rozumu. Ono odgrywa podstawową rolę w całym procesie poznawczym. Jak trafnie zauważa Stróżewski, dla racjonalisty rozum posiada najwyższą wartość poznawczą, nie zaś szeroko pojmowane doświadczenia empiryczne bądź mistyczne ${ }^{15}$. Racjonalność stoi bowiem w opozycji do tych dwóch sposobów poznania, na co trafnie zwrócił uwagę także Tatarkiewicz ${ }^{16}$.

${ }_{13}$ Por. np. R. Kleszcz, O racjonalności, Studium epistemologiczno-metodologiczne, Łódź 1998, s. 35-36; także: Racjonalizm, http://www.ptta.pl/pef/pdf/r/racjonalizm.pdf, s. 1.

${ }_{14}$ Zob. W. Tatarkiewicz, O niektórych postaciach racjonalizmu XVII i XVIII wieku, w: W. Tatarkiewicz, Droga do filozofii i inne rozprawy filozoficzne, Warszawa 1971.

${ }_{15}$ Zob. W. Stróżewski, Istnienie i sens, Kraków 1994, s. 396-398; zob. także: M. Gajewski, Funkcje i dysfunkcje myślenia irracjonalnego, „Annales UMCS” sec. I (Philosophia-Sociologia) 42, 2 (2017), s. 9-10.

${ }^{16}$ Zob. W. Tatarkiewicz, O niektórych postaciach racjonalizmu..., dz. cyt., s. 114. 
Według zarysowanej przed chwilą postaci racjonalizmu poznajemy, ponieważ posiadamy idee wrodzone (natywizm) w naszym intelekcie. Natura zaś poznania polega na zrozumieniu, które swą prawomocność opiera albo na samym rozumowaniu (aprioryzm; tu racjonalizm występuje przeciwko empiryzmowi), albo na połączniu rozumu z doświadczeniem (można także powiedzieć, że rozum poznaje/opracowuje doświadczenie; w tym przypadku racjonalizm występuje przeciwko np. mistycyzmowi ${ }^{17}$.

XVIII-wieczni krytycy racjonalizmu (np. Kant) dostrzegli jeszcze jedną ważną jego cechę, która objawiła się jako konsekwencja tak pojmowanego procesu poznawczego. Chodzi o wspomniany wcześniej dogmatyzm, czyli tendencję do apriorycznego przyjmowania jednej lub kilku zasad niezależnych od doświadczenia, na których zostaje oparta cała wiedza, jak również proces jej zdobywania ${ }^{18}$. Racjonalizm, stawiając wyżej poznanie rozumowe, wcale nie przekreśla innych źródeł poznania, po prostu twierdzi jedynie, że jest poznaniem bardziej jasnym, wyraźnym i oczywistym. Tymczasem dogmatyzm, o którym mowa, w ogóle nie zauważa żadnych innych źródeł niż sam rozum i jego dane. I widać, niestety, że w tym jedynym punkcie postmodernizm ma bardzo wiele wspólnego $\mathrm{z}$ racjonalizmem dogmatycznym, a właściwie $\mathrm{z}$ jego nieokiełznana intelektualnie konsekwencją.

\section{B. Irracjonalizm}

Ponieważ stwierdzone już zostało, że postmodernizm jest współczesną odmianą irracjonalizmu, spójrzmy zatem pokrótce także i na to zagadnienie. Podobnie jak pojęcie racjonalizmu, trudno jest jednoznacznie zdefiniować zagadnienie irracjonalizmu. Dlatego też pomijając głębsze analizy tego problemu $^{19}$ i biorąc pod uwagę temat niniejszej pracy, wypada zauważyć cztery jego typy, niezwykle charakterystyczne także dla myślenia postracjonalego: ontologiczny, epistemologiczny, logiczny i etyczny ${ }^{20}$.

Wedle irracjonalizmu ontologicznego cała rzeczywistość jest irracjonalna. Nie można jej w żaden sposób uporządkować, gdyż u jej podstaw leżą siły bezrozumne, bezcelowe i bezładne, jak np. wola w ujęciu Schopenhauera.

${ }_{17}$ Por. M. Gajewski, Funkcje i dysfunkcje myślenia irracjonalnego, dz. cyt., s. 10.

18 Por. http://www.ptta.pl/pef/pdf/r/racjonalizm.pdf, s. 2.

19 Wypada zwrócić tu uwagę na ciekawą pracę opisującą systematycznie zagadnienie irracjonalizmu oraz irracjonalności, zob. J. Szmyd, Myślenie i zachowanie nieracjonalne, Katowice 2012.

${ }^{20}$ Por. M. Gajewski, Funkcje i dysfunkcje myślenia irracjonalnego, dz. cyt., s. 12-15. 
Ponieważ nie ma w niej obiektywnych praw logicznych, jawi się naszemu umysłowi jako paradoksalna. Co więcej, wszelkie pojęcia, terminy, zasady naukowe i filozoficzne są jedynie konstrukcjami umysłu, niemającymi realnego uzasadnienia. Ich stosowanie nie tylko nic ważnego nie mówi o rzeczywistości, ale właściwie ją deformuje ${ }^{21}$.

W bardzo podobny sposób irracjonalizm odnosi się do problemu poznania. Jak twierdzą jego zwolennicy, racjonalne poznanie jest właściwie ułudą oraz pobożnym życzeniem, a to dlatego, że: (1) nie da się racjonalnie poznać w pełni rzeczywistości (agnostycyzm), (2) poznanie racjonalne deformuje i spłyca obraz świata (fenomenalizm), (3) całkowicie subiektywizuje świat (subiektywizm), (4) sprowadza świat jedynie do symbolicznego obrazu (symbolizm), (5) poznanie naukowe u racjonalistów jest jedynie zbiorem arbitralnych konwencji i fikcji (konwencjonalizm i fikcjonalizm), (6) bardzo często potrzeby praktyczne ograniczają zdolności i zakres poznania (praktycyzm epistemologiczny). Jakie zatem powinno być to lepsze, irracjonalne poznanie? Przede wszystkim trzeba odrzucić rozum i jasne dla niego zasady, a opierać się na instynkcie, intuicji oraz natchnieniu mistycznym. Tym, co naprawdę posiada wartość poznawczą, są niekomunikowalne odczucia, przeżycia oraz zdania niezgodne z prawidłami tradycyjnej logiki, nie zaś sądy empiryczne lub poznanie dyskursywne ${ }^{22}$.

Irracjonalizm, to jak widać, nowa logika. Dla zwolenników tego typu myślenia coś jest irracjonalne w sensie logicznym, czyli ważniejsze, lepsze, bardziej sensowne i adekwatne względem świata i człowieka, wtedy i tylko wtedy, gdy: (1) jest niemożliwe logicznie lub (2) niemożliwe empirycznie, albo (3) zasadniczo nierozstrzygalne. Nic więc dziwnego, że poznawczo poprawne są dla nich zarówno takie zdania, które przyjmują istnienie przedmiotów wewnętrznie sprzecznych (np. „,koło jest kwadratem”), jak również takie, które co prawda nie są sprzeczne logicznie, ale zakładają istnienie przedmiotów, których nie da się zweryfikować empirycznie (np. „wszechświat ma swoją pierwszą przyczynę”; „Kopernik ruszył ziemię, wstrzymał słońce” $)^{23}$.

${ }^{21}$ Por. M. Gajewski, Funkcje i dysfunkcje myślenia irracjonalnego, dz. cyt., s. 13.

${ }^{22}$ Por. M. Gajewski, Funkcje i dysfunkcje myślenia irracjonalnego, dz. cyt., s. 13; zob. także: J. Szmyd, Myślenie i zachowanie nieracjonalne, dz. cyt., s. 23.

${ }_{33}$ Por. M. Gajewski, Funkcje i dysfunkcje myślenia irracjonalnego, dz. cyt., s. 13-14; zob. także: I. Dąbska, Irracjonalizm a poznanie naukowe, „Kwartalnik Filozoficzny” 1938 nr 1, s. 90; J. Szmyd, Myślenie i zachowanie nieracjonalne, dz. cyt., s. 23. Widać na przykładzie podanych zdań logiki irracjonalnej, iż trudno się z nimi nie zgodzić, choć są one jedynie poetycką przenośnią lub bardziej pragnieniem intelektualnym, niż odczytaniem zaistniałego faktu. 
Irracjonalizm przejawia się również, niestety, w etyce. Skoro nie ma obiektywnej i jasnej logiki ani metafizyki, nie ma również pojęcia prawdy, ani obiektywnego systemu wartości. Zwolennicy tego typu myślenia są więc przekonani, że oceny i normy moralne nie powinny być oparte na racjonalnej i logicznej argumentacji, odniesionej do ogólnych i niezmiennych prawd i wartości, oraz niezbywalnych i trwałych relacji między nimi, lecz na intuicji, czystych emocjach $i$ uczuciach. Potrzeba takich właśnie, bardziej adekwatnych do rzeczywistości podstaw moralnych także dlatego, że w naszym postępowaniu, o czym mówi codzienne doświadczenie, nie podążamy jedynie za intelektualną refleksją, ale dużo częściej - a niekiedy tylko - za elementami irracjonalnymi, takimi jak: kompleksy, popędy, instynkty itp. ${ }^{24}$. Oczywiście, tak pojmowana etyka wydaje się wielu komentatorom nie tylko dziwna, lecz także groźna. Dziwna, gdyż ogranicza człowiekowi możliwość wolnego, kreatywnego i odpowiedzialnego działania, a groźna, gdyż przenikając do innych dziedzin nauki i życia społecznego, staje się silnym przyczynkiem do ich ideologizacji ${ }^{25}$. Zauważyła to już m.in. Izydora Dąbska, gdy w 1938 roku pisała o moralności irracjonalnej: „...bardziej ludzki i mniej niebezpieczny jest człowiek, który szanuje zasadę sprzeczności i z doświadczeniem się liczy, niż ten, kto gotów wierzyć w zdania wewnętrznie sprzeczne i zasadniczo nierozstrzygalne, tą swoją wiarą w życiu się kierować i innych na nią nawracać"26.

\section{Filozofowanie w duchu postmodernizmu}

Analizując bliżej wypowiedzi współczesnych humanistów ponowoczesnych ${ }^{27}$, łatwo zauważyć, że ich myśl jest współczesną odmianą irracjonalizmu. Po cóż

${ }^{24}$ Por. J. Szmyd, Myślenie i zachowanie nieracjonalne, dz. cyt., s. 32-34.

${ }_{25}$ Por. M. Gajewski, Funkcje i dysfunkcje myślenia irracjonalnego, dz. cyt., s. 14-15. Można zwrócić uwagę także na fakt np. licznych i niezrozumiałych społecznie decyzji wymiaru sprawiedliwości, świadczących o różnej ocenie tych samych czynów u różnych obywateli, zob. Potrącił 77-latkę na pasach?, https://wpolityce.pl/spoleczenstwo/451709-potracil-kobiete-na-pasach-co-z-tegonajsztub-uniewinniony (21.06.2019) itp.

${ }^{26}$ Cytat za: M. Gajewski, Funkcje i dysfunkcje..., dz. cyt., s. 15 .

${ }^{27}$ Np. J-F. Lyotard, The postmodern condition, dz. cyt.; J.-F. Lyotard, J.-L. Thébaud, Just Gaming, dz. cyt.; K. R. Popper, Nędza historycyzmu, przeł. S. Amsterdamski, Warszawa 1989; Z. Bauman, Etyka ponowoczesna, przeł. J. Bauman, J. Tokarska-Bakir, Warszawa 2012; Z. Bauman, Płynna nowoczesność, przeł. T. Kunz, Kraków 2008; F. Fukuyama, Koniec historii, przeł. T. Bieroń, Poznań 200o; F. Fukuyama, Wielki wstrzą: natura ludzka a odbudowa porządku społecznego, przeł. H. Komorowska, K. Dorosz, Warszawa 200o; J. Derrida, É. Roudinesco, Pochwała psychoanalizy, 
zatem niektórzy z nich tak usilnie próbują uprawomocnić swoje dociekania w sposób, niech mi będzie wolno napisać, racjonalny i obiektywny? Czyżby szukali potwierdzenia dla swoich analiz w terminach i metodach nauk szczegółowych? A może jednak chodzi im o to, by wszelkie nauki szczegółowe ukazać jedynie jako „narrację i mit, lub jeden z wielu społecznych konstruktów”, jak wskazywali na to Alan Sokal i Jean Bricmont w cytowanej na początku artykułu książce Modne bzdury...? Wydaje się, że mamy do czynienia raczej z tym drugim przypadkiem. Bardzo często potrzebują oni dziedzictwa racjonalizmu, by ukazać wyższość swoich badań nad naukami szczegółowymi, a przez działania pozornie racjonalne dotrzeć do jak największej liczby słuchaczy. Inaczej przecież nie będzie można stworzyć ani nowego człowieka, ani nowego świata, co jest głównym celem ich poczynań. Jest to działanie dosyć podstępne, gdyż pod płaszczykiem ściśle naukowej metody dokonuje się redukcjonistycznych działań w dziedzinach humanistycznych, które są bliskie każdemu człowiekowi. O ile mało kogo interesuje np. teoria względności Einsteina czy liczby urojone, o tyle wszyscy przecież jesteśmy, mniej lub bardziej, zainteresowani życiem społecznym, politycznym czy prawami oraz kondycją współczesnego człowieka. Wskażmy tylko kilka przykładów takiego postępowania metodologicznego ${ }^{28}$ zwolenników postmodernizmu.

Nie chodzi tu jedynie o to, by na siłę wskazać mocne przykłady niekonsekwencji i nadużyć ze strony niektórych humanistów postracjonalnych, ale o to, by zobaczyć, jak nie do końca radzą oni sobie w rozumieniu specyfiki nauk szczegółowych oraz uzasadnianiu na ich podstawie swoich tez, przez co sami o sobie wydają niezbyt pochlebną opinię. Chodzi również o to, by zwrócić na to uwagę dzisiejszym czytelnikom, przyjmującym zbyt pochopnie każdy tekst postmodernistycznego humanisty, który na pierwszy rzut oka wydaje się niezwykle odkrywczy czy błyskotliwy. Skupimy się na trzech postaciach ważnych zarówno dla niniejszego tematu, jak i dla wskazanego typu filozofowania. Będą nimi: Bruno Latour, Jean Baudrillard oraz Jacques Lacan. Bardzo ogólnie mówiąc, Latour próbował uprawomocnić naukami szczegółowymi nowe tezy socjologiczne, Baudrillard wskazywał na pewne mechanizmy zachodzące w kulturze, Lacan natomiast uchodził za odnowiciela myśli Freuda.

przeł. M. Loba, „Literatura na Świecie” 2003 nr 3-4, s. 273-308; J. Derrida, Różnicość, http:// bb.ph-f.org/przeklady/derrida_roznicosc.pdf (21.06.2019); J. Kristeva, Sìmeiōtikī: recherches pour une sémanalyse, Paris 1969 itd.

${ }_{28}$ Na podobne problemy wskazywałem już w artykułach: Flew i Kistevej „poszukiwanie” Boga oraz Postmodernizm - od filozofii do mitu?, "Theofos” 2019 nr 5, s. 38-53 oraz s. 103-111. 
A socjologia, kultura i psychoanaliza to zagadnienia naprawdę ważne dla postmodernizmu. Oczywiście nie wszyscy przedstawiciele owego nurtu czynią tak poważne błędy. Wypada podać tu przykład polskiego socjologa i filozofa, zwanego przez niektórych nawet prorokiem postmodernizmu, Zygmunta Baumana, którego postępowanie metodologiczne oparte jest na mocnych, naukowych podstawach ${ }^{29}$.

Latour, francuski antropolog, filozof nauki, a - przede wszystkim - socjolog, najbardziej znany ze swego dzieła La Science en action. Introduction à la sociologie des sciences ${ }^{30}$, w mniej znanej pracy A relativistic account of Eistein's relativity ${ }^{31}$ próbuje odczytać tekst Einsteina jako wkład do tzw. socjologii delegacji. Autor jest tu zwolennikiem tezy rozwijającej się w łonie socjologii nauki, że treść dowolnej nauki jest dogłębnie społeczna. Ubolewa, iż wcześniejsze analizy teorii względności Einsteina dokonywane przez socjologów zupełnie pomijały matematyczne aspekty owej teorii, a co za tym idzie, nie zauważały, w jakim sensie jest ona, sama w sobie, jednocześnie, a może nawet bardziej, teorią socjologiczną. Przystępuje zatem do analizy teorii Einsteina, niwelując ten brak. Aby to uczynić, stawia sobie dwa podstawowe pytania ${ }^{32}$ : (1) czy i w jaki sposób, ucząc się od Einsteina, możemy badać społeczeństwo, (2) w jaki sposób, na nowo formułując pojęcie społeczeństwa, możemy zrozumieć pracę Einsteina jako explicite społeczną? ${ }^{33}$

Latour poddaje semiotycznej, a zatem humanistycznej, analizie książkę Einsteina Relativity: The Special and the General Theory, a socjologicznie rozumiane terminy wysuwanie i wycofywanie narratorów próbuje zastosować do jego teorii względności. Niestety, błędnie rozumie pojęcie układu odniesienia w fizyce, co stawia pod wielkim znakiem zapytania wnioski, do których dochodzi. Nie wchodząc głębiej w problematykę, w której nie jestem i nie czuję się zupełnie kompetentny, wypada najpierw nieśmiało naszkicować, co to jest, w ogóle, układ odniesienia w fizyce i jak wyglądają relacje pomiędzy dwoma takimi układami ${ }^{34}$.

${ }^{29}$ Por. np. D. Smith, Zygmunt Bauman: Prophet of Postmodernity, Cambridge 1999; A. Duk, Zarys ateizmu postmodernistycznego Zygmunta Baumana, „Theofos” $2020 \mathrm{nr} 6$, s. 101-119.

${ }^{30}$ B. Latour, La Science en action. Introduction à la sociologie des sciences, Paris 1989.

${ }^{31}$ B. Latour, A relativistic account of Eistein's relativity, „Social Studies of Science” 1988 no. 18, s. $3-44$.

${ }^{32}$ Zob. B. Latour, A relativistic account of Eistein's relativity, dz. cyt., s. 5, 35-36.

33 Por. A. Sokal, J. Bricmont, Modne bzdury..., dz. cyt., s. 124-131.

${ }^{34}$ Por. A. Sokal, J. Bricmont, Modne bzdury..., dz. cyt., s. 125. 
Jak trafnie zauważają specjaliści w dziedzinie fizyki, Sokal i Bricmont, jest to schemat przypisywania konkretnym zdarzeniom współrzędnych w przestrzeni i czasie. Owe zaś współrzędne można przedstawić w sposób liczbowy i geometryczny, jako układ wzajemnie prostopadłych prętów pomiarowych, na których jesteśmy w stanie umieszczać dane konkretnego wydarzenia. Dzięki takiemu postępowaniu można każdemu zdarzeniu przypisać współrzędne: gdzie i kiedy, np.: na skrzyżowaniu ulicy $x$ oraz $y$, na wysokości $z$, o godzinie $t$. Tak pojmowany układ odniesienia wymaga, oczywiście, kilku arbitralnych decyzji, np.: gdzie umieścić początek owego układu, w którym kierunku skierować osie odniesienia, czy: od jakiej chwili liczyć czas całego wydarzenia. Według fizyków takie pytania nie są jednak w żaden sposób problematyczne, gdyż w każdej chwili, zmieniając początek układu, liczenie czasu czy kierunek osi, a zatem zmieniając współrzędne całego wydarzenia, za pomocą prostych wzorów, moglibyśmy przeliczyć owe współrzędne z jednego układu na drugi. Sytuacja zasadniczo komplikuje się wtedy, gdy mamy wobec jednego wydarzenia dwa różne i poruszające się względem siebie układy odniesienia. Rodzą się tu dwa zasadnicze pytania nowożytnej fizyki (od czasów Galileusza): (1) czy prawa fizyki w obu takich układach odniesienia mają taką samą postać, oraz (2) z jakich wzorów i równań trzeba skorzystać, aby przejść z jednego do drugiego zbioru współrzędnych. Właśnie tych dwóch problemów dotyczy teoria względności Alberta Einsteina ${ }^{35}$.

Fizycy Sokal i Bricmont zauważają, że w popularnej, pedagogicznej prezentacji układ odniesienia, a dokładniej mówiąc, układ współrzędnych w teorii względności, można luźno kojarzyć z pojęciem obserwatora lub zbiorem obserwatorów, po jednym w każdym punkcie przestrzeni (x, y, z). Mogą nimi być zarówno ludzie, jak i maszyny. Mogą oni również pozostawać względem siebie w spoczynku, będąc jednak wyposażonymi w odpowiednio zsynchronizowane zegary, ze względu na fakt, iż wszystkie owe zegary znajdują się w ruchu względem czegoś innego. Takiego układu odniesienia nie trzeba jednak wcale konstruować. Wystarczy, że wyobrazimy sobie, iż jest on związany z np. protonem, poruszającym się pod wpływem zderzenia o bardzo dużej energii. Niestety, Latour nie zauważa - być może nie do końca świadomie - iż jego wizja fizycznej przecież teorii jest niewłaściwa. Popełnia trzy poważne błędy: (1) twierdzi, że teoria względności zajmuje się nie ruchem, lecz względnym położeniem różnych układów odniesienia ${ }^{36},(2)$ myli pojęcie układu odniesienia

35 Por. A. Sokal, J. Bricmont, Modne bzdury..., dz. cyt., s. 125.

${ }^{36}$ Zob. B. Latour, A relativistic account of Eistein's relativity, dz. cyt., s. 6, 14, 22-23, 24. 
$\mathrm{w}$ fizyce oraz aktora w semiotyce ${ }^{37}$, (3) podkreśla, zupełnie niesłusznie, rolę enuncjatora (autora) ${ }^{38}$ jako nieredukowalnego i nieprzekładalnego punktu odniesienia. Szczególnie w tym ostatnim punkcie widać zupełnie uprzywilejowaną rolę, którą enuncjatorowi przypisuje francuski socjolog, a czego, po prostu, nie ma w samej teorii względności ${ }^{39}$.

Nie wchodząc $w$ bardziej dokładne analizy popełnionych przez Latoura błędów w rozumieniu i stosowaniu teorii względności w badaniach socjologicznych, wypada zwrócić uwagę na jeszcze jeden, dosyć ciekawy fakt. Dotyczy on niejasnego, naciaganego rozumienia terminów niedotyczących bezpośrednio Einsteinowskiej teorii. Jak stwierdza choćby matematyk i fizyk Tobias Hurth, znaczenie jednego z podstawowych przecież dla socjologii pojęcia „społeczeństwo", jak również bardziej metodologicznego „abstrakcja”, wydaje się sztucznie dopasowane przez Latoura do jego interpretacji teorii względności. Francuski socjolog nie tylko nie zinterpretował na nowo metody badań społeczeństwa, dając być może jego nową definicję, co pierwotnie sobie założył, ale wprowadził dużo więcej chaosu i w teorię fizyczną, i dociekania socjologiczne. Bo i po cóż, na przykład, tłumaczyć innym socjologom zagadnienia socjologiczne, uciekając się do teorii fizycznych? Czyżby nie do końca ufał swoim badaniom? A Latour tak właśnie czyni ${ }^{40}$.

Inny francuski filozof i socjolog, Baudrillard, którego pracami na temat natury rzeczywistości, jej przejawami i iluzją zachwyca się naprawdę wielu ${ }^{41}$, wykorzystuje pojęcia nauk szczegółowych w sobie właściwy sposób: czasem metaforyczny, czasem nie. Kiedy i dlaczego właśnie tak, a nie inaczej, nie do końca wiadomo. Niestety, do swoich badań dołącza także terminy, które $\mathrm{z}$ nauką nie mają wiele wspólnego.

W sposób jawnie metaforyczny wykorzystuje pojęcie „przestrzeni euklidesowej” (pojawia w jego tekście dosłowne stwierdzenie „przestrzeń

37 Zob. B. Latour, A relativistic account of Eistein's relativity, dz. cyt., s. 10-11, 19, 22, 43.

${ }_{38}$ Zob. B. Latour, A relativistic account of Eistein's relativity, dz. cyt., s. 10-11, 19, 22, 43.

39 Por. A. Sokal, J. Bricmont, Modne bzdury..., dz. cyt., s. 126-130.

${ }^{40}$ Por. A. Sokal, J. Bricmont, Modne bzdury..., dz. cyt., s. 98, 124-125, 131. Por. także: O. Amsterdamska, Surely are you joking, Monsieur Latour, „Science, Technology \& Human Values” 15 (1990) issue 4, s. 495-504; Y. Gingras, Un air de radicalisme: Sur quelques tendances récentes en sociologie de la science et de la technologie, „Actes de la recherche en sciences sociales” 1995 $\mathrm{n}^{\mathrm{o}} 108$, s. $3-17$.

${ }^{41}$ Słowa niezwykle pozytywne, o „nowym i precyzyjnym” ujęciu zjawisk socjologicznych można znaleźć np. we francuskim „Le Monde”, na który powołują się Sokal i Bricmont na s. 144 cytowanej książki. 
nieeuklidesowa”) do opisu wojny w Zatoce Perskiej. W iście poetycki i jasny chyba tylko sobie sposób pisze o tym tragicznym wydarzeniu jako o pewnym (uwaga!) wyniku, czy może lepiej, zrealizowaniu się w czasie rzeczywistym i w tej samej przestrzeni dwóch, połączonych ze sobą w nieubłaganym wyścigu, hipotez: apokalipsy i wojny w czasie rzeczywistym oraz triumfu wirtualnego świata nad realnym. Na dodatek tak widziane zdarzenie spowodowało, iż rzeczywista przestrzeń, w której się ono pojawiło, stała się „hiperprzestrzenią wielokrotnego załamania”, zaś przestrzeń wojny „zdecydowanie nieeuklidesową" ${ }^{42}$. Niestety, chyba nikt nie jest w stanie opisać, jak wygląda „euklidesowa przestrzeń wojny” lub co znaczy pojęcie „hiperprzestrzeń wielokrotnego załamania”. Ten ostatni termin pozornie tylko wygląda na matematyczny lub fizyczny, w rzeczywistości bowiem te dwie nauki ścisłe nie znają takiego pojęcia. Jest on zatem jedynie wynalazkiem francuskiego socjologa stworzonym zapewne na użytek chwili. Do tej krótkiej refleksji należy dodać jeszcze kilka innych pojęć, używanych metaforycznie, jak: „euklidesowa przestrzeń historii”, „liniowa przestrzeń Oświecenia”, czy zjawisko tzw. „zabawnej fizyki”, która podobno wtłacza zdarzenia indywidualne lub zbiorowe $\mathrm{w}$ „dziurę pamięci” ${ }^{43}$.

Obok stosowania terminów nauk ścisłych w sposób metaforyczny, Baudrillard używa ich także dosłownie, choć przyznać trzeba, iż jest to jego własna wersja fizyki ${ }^{44}$. Tak jest np. w przypadku kwestii losowości, gdy socjolog uważa, że dzięki niej w dzisiejszej nauce coraz częściej trzeba zauważać nowy fakt odwracania praw fizyki. Według niego wielkie systemy metafizyczne ${ }^{45}$ już wcześniej głosiły hipotezę sprzeciwiającą się nieodwracalnemu porządkowi praw,

${ }^{42}$ J. Baudrillard, The Gulf War Did Not Take Place, trans. \& intro. P. Patton, Bloomington 1995, s. 50. Można zwrócić tu uwagę na ciekawy fakt, specyficzny dla myślenia postmodernistycznego. Sam tytuł dzieła Baudrillarda sugeruje, że wojny w Zatoce Perskiej właściwie nie było. Jeśli zaistniałyby w innym miejscu i czasie przedstawione przez socjologa okoliczności, powinno „wydarzyć się" dokładnie to samo. Problem jednak w tym, iż wizja piszącego jest niestety redukcjonistyczna, bardzo często oparta na własnych i cząstkowych wyobrażeniach, a zatem nie bierze się tu pod uwagę wielu, nieznanych piszącemu faktów, które spowodowały, że właśnie to i w ty m miejscu jednak się rzeczywiście wydarzyło. Wyobrażenia autora, fikcja i rzeczywistość, niestety, jakoś mieszają się ze sobą.

43 A. Sokal, J. Bricmont, Modne bzdury..., dz. cyt., s. 144-145.

${ }_{44}$ Zob. J. Baudrillard, Fatal strategies, trans. P. Beitchman, W. G. Niesłuchowski, ed. J. Fleming, New York 1990; J. Baudrillard, The Transparency of Evil: Essays on Extreme Phenomena, trans. J. Benedict, London 1993; J. Baudrillard, The Illusion of the End, trans. C. Turner, Cambridge, England 1994 .

${ }^{45}$ Widać tu wyraźnie, że Baudrillard nie zna bądź nie rozumie metafizyki arystotelesowsko-tomistycznej. 
czasu i znaczenia. Niestety nie zauważa, że rzekomo nowe odkrycia w fizyce są dobrze znane dynamice, zarówno przyczynowej, jak i deterministycznej Newtona, jako jedna z solidniej wyrażanych teorii. Poza tym myli on pojęcie odwracalności praw z odwracalnością porządku przyczynowego (związek przyczyna-skutek), uznając je właściwie za synonimy, co oczywiście nie jest prawdą z punktu widzenia fizyki ${ }^{46}$.

Wydaje się, że porządek przyczynowo-skutkowy jest szczególnie nielubiany i atakowany przez postracjonalnych humanistów. Baudrillard wraca do jego krytyki przy okazji swoich dywagacji na temat końca jako takiego, w szczególności zaś końca historii ${ }^{47}$. W jego opinii rozważania na temat końca wydają się paradoksalne: z jednej bowiem strony wykraczają poza kres naszego poznania, z drugiej, w „nieeuklidesowej przestrzeni historii” (?), którą założył, nie można jej w ogóle zlokalizować. Koniec jest pewnym wynikiem działania przyczynowo-skutkowego, tymczasem wydarzenia, które brały udział w danym ciągu działań, mogą być sztucznie wytworzone na każdym etapie owego działania, podobnie jak dzieje się to - i tu leży błąd niezrozumienia - w fizycznej teorii chaosu. Przyczynowość jako taka nie ma żadnego sensu, jak choćby dopatrywanie się zależności pomiędzy uderzeniem skrzydeł motyla na jednym końcu świata a huraganem na drugim. Ponadto, odwrócony bieg historii można porównać do pewnego rodzaju turbulencji, w której poszczególne zdarzenia są odwracane lub, jak sam pisze, połykane. Niestety, stwierdzić trzeba, iż fizyczna teoria chaosu, na którą powołuje się francuski filozof i socjolog, wcale nie odwraca związku przyczynowo- skutkowego. Po prostu trzeba było ją najpierw zrozumieć, zanim się zbyt pochopnie na nią powołano ${ }^{48}$.

Ogólnie mówiąc, myśl Baudrillarda w swojej treści i przekazie jest dużo bardziej pompatyczna i bezsensowna, jak twierdzą niektórzy ${ }^{49}$, niż precyzyjna i klarowna. Jeśli dodamy do tego także typowo pseudonaukowe terminy, jak: „hiperprzestrzeń o zmiennej refrakcji” czy „rozrastanie się fraktala przez podział", możemy śmiało powiedzieć, że całość jego wywodów zawarta w cytowanych tu pracach, to nie tyle solidne dociekania naukowe, ile raczej skomplikowana i niejasna wizja początkujacego poety. Dlatego na pytanie

${ }^{46}$ Por. A. Sokal, J. Bricmont, Modne bzdury..., dz. cyt., s. 145-146.

47 Zob. J. Baudrillard, The Illusion of the End, dz. cyt.

${ }^{8}$ Por. A. Sokal, J. Bricmont, Modne bzdury..., dz. cyt., s. 145-147.

49 Por. P. R. Gross, N. Levitt, Higher Superstition: The Academic Left and Its Quarrels with Science, Baltimore 1994, s. 8 o. 
Sokala i Bricmonta: „co pozostałoby z myśli Baudrillarda, gdyby odrzeć ją ze słownego przybrania”, naprawdę ciężko byłoby odpowiedziećso .

Postmodernistyczni humaniści nie tylko w naukach szczegółowych, lecz także poza nimi, szukają potwierdzenia dla swoich płynnych rozważań. $\mathrm{W}$ ich opinii odpowiednią do tego jest freudowska psychoanaliza. Wydaje się, że najbardziej znanym postmodernistą, próbującym uczynić z psychoanalizy naukę jasną i powszechnie akceptowaną, która dostarczyła wreszcie myśli Freuda niezbędnych pojęć naukowych ${ }^{51}$, jest Jacques Lacan (1901-1981). Ten francuski psychiatra i psychoanalityk, głoszący tezę powrotu do Freuda, uważany był za jednego z najbardziej wpływowych psychoanalityków XX wieku, co wcale nie oznacza, iż jego prace były przyjmowane bezkrytycznie. Gdy zwolennicy twierdzili, że zrewolucjonizował teorię i praktykę psychoanalizy, przeciwnicy głosili, że jego badania to czyste wodolejstwo, zaś on sam wydaje się być dużo bardziej szarlatanem niż poważnym naukowcem. Nie chodzi jednak w tym miejscu o ocenę prac psychoanalitycznych, ale o - ponownie! - nadużycia pojęć matematycznych do ugruntowania, tym razem, psychoanalitycznych badań $^{52}$. Okazuje się bowiem, co jest naprawdę kontrowersyjne metodologicznie, że także psychoanaliza, która ma być podstawą dla postmodernistycznego myślenia, sama jest gruntem bardzo chwiejnym i niejasnym ${ }^{53}$.

Lacan dosyć wcześnie ucieka się do badań matematycznych, pragnąc wyjaśniać nimi swoje psychologiczne dywagacje. Już w $1959^{54}$ roku próbuje interpretować życie ludzkie jako matematyczny rachunek, „w którym zero jest niewymierne”, co oznacza dla niego jednocześnie, iż jest urojone. Widać tu wyraźnie, jak myli on pojęcie liczb niewymiernych i urojonych. Rozumie je bowiem w sensie języka potocznego, a nie naukowego, a to dwa zupełnie różne sposoby opisywania rzeczywistości. I choć zaznacza w swoim tekście, że porównanie to jest jedynie metaforyczne, trudno dokładnie określić, jak rozumieć tak sformułowaną wypowiedź. Mówiąc inaczej, po co odwoływać się do nauki ścisłej, by coś wyjaśnić, jeśli wciąż przebywamy w świecie metafor? ${ }^{55}$

5o Zob. A. Sokal, J. Bricmont, Modne bzdury..., dz. cyt., s. 148-150.

${ }^{51}$ Por. np. L. Althusser, Écrits sur la psychanalyse, Paris 1993, s. 50; J.-C. Milner, L'ouvre claire, Paris 1995, s. 7 .

${ }^{52}$ Por. A. Sokal, J. Bricmont, Modne bzdury..., dz. cyt., s. 31-48.

${ }_{53}$ Por. np. R. Stachowski, Historia współczesnej myśli psychologicznej, Warszawa 200o; M. Macmillan, Freud oceniony. Analiza krytyczna dzieła, przeł. M. Zagrodzki, Kraków 2007.

${ }_{54}$ Zob. J. Lacan, Desire and the interpretation of desire in Hamlet, trans. J. Hulbert, „Yale French Studies" 1977 no. 55/56, s. 11-52.

55 Por. A. Sokal, J. Bricmont, Modne bzdury..., dz. cyt., s. 37-39. 
Uprawomocnienia psychoanalizy - niech wolno mi będzie tak napisać szuka Lacan przede wszystkim w topologii. Topologia zaś jest dziedziną matematyki zajmującą się głownie własnościami obiektów geometrycznych, takich jak: powierzchnia, bryła itp., które nie zmieniają się, gdy badany obiekt zostaje przekształcony bez klejenia i rozrywania. Dosyć wcześnie w swoich pracach umieszcza Lacan odniesienia do topologii, choć pierwszym dłuższym i bardziej znanym tekstem na ten temat jest jego wypowiedź na konferencji zorganizowanej przez uniwersytet Hopkinsa w $1966 \mathrm{roku}^{56}$. W tym właśnie tekście pojawiają się porównania struktury chorób umysłowych do obiektów topologicznych, takich jak: torus, butelka Kleina czy czapa krzyżowa. Co więcej, według francuskiego psychiatry torus, czyli topologiczny obiekt matematyczny, bardzo dokładnie odzwierciedla strukturę neurotyka. Niestety, nigdzie w tekście nie można znaleźć żadnych sensownych analiz potwierdzających w ogóle związek między topologią a chorobami umysłowymi. Nie ma też żadnego konkretnego i sensownego badania, które mogłoby wskazywać na tę szczególną zależność, jaka ma być pomiędzy strukturą neurotyka a torusem. Autor, po prostu, tak zakłada. W jego opinii to fakt, a nie żadna analogia, którą explicite odrzuca ${ }^{57}$.

W miarę upływu lat i rozwoju naukowego Lacan wcale nie odchodzi od prób tłumaczenia problemów natury psychicznej zdobyczami matematyki. W innym swoim wykładzie powołuje się na cztery terminy z dziedziny matematycznej (przestrzeń, zamknięty, ograniczony, topologia), opisując trudne do jednoznacznej definicji, także dla psychologa, pojęcie rozkoszy. Przypisuje mu np. właściwości przestrzeni w sensie matematycznym, choć nigdzie nie dostarcza argumentów, które uzasadniałyby takie odniesienie. Podobnie jest $\mathrm{z}$ teorią zawartości. Lacan nie dość, że fałszywie ją rozumie, to dodatkowo twierdzi, że jego analizy dotyczą najświeższych osiągnięć w tej dziedzinie matematyki, co nie jest wcale prawdą, gdyż powołuje się na badania z początku XX wieku $(1900-1930)^{58}$.

Do zasygnalizowanych już zarzutów można dodać jeszcze Lacana problemy ze zrozumieniem i nieuprawomocnionym odniesieniem logiki matematycznej do psychoanalizy i lingwistyki. I nie chodzi w tym momencie tylko o sens czy sposób ich wzajemnego odniesienia, jak do tej pory staraliśmy się to ukazywać,

${ }^{56}$ Zob. J. Lacan, Of structure as an inmixing of an otherness prerequisite to any subject whatever, trans. A. Lewańska, w: Languages of Criticism and the Sciences of Man, ed. R. Macksay, E. Donato, Baltimore 1970, s. 186-200.

57 Por. A. Sokal, J. Bricmont, Modne bzdury..., dz. cyt., s. 31-33.

${ }_{58}$ Por. A. Sokal, J. Bricmont, Modne bzdury..., dz. cyt., s. 33-37. 
lecz także o jakość uprawianej matematyki. Sokal i Bricmont twierdzą wprost, że matematyka Lacana jest tak dziwaczna, iż nie może przynieść żadnego pożytku analizie psychologicznej, do której przecież z powodzeniem można by było ją zastosować. Nie jest czymś zaskakującym, że tak młoda dziedzina wiedzy jak psychoanaliza szuka potwierdzenia w sensownych i odpowiednich działaniach matematycznych. Bardziej zaskakujące może być uciekanie się do badań, które racjonalnie trudno zaakceptować, gdyż nie do końca wiadomo, czy ich metodę odpowiednio zrozumiano, dobrano, zastosowano i zinterpretowano. Psychoanalizie przydałyby się jakieś konkrety empiryczne, np. potwierdzone obserwacje. A zatem nie chodzi tu tylko o jakość badań psychologicznych czy psychoanalitycznych, ale również o to, czy jeszcze - w ogóle - z matematyką mamy tam do czynienia? A może cały intelektualny wysiłek francuskiego humanisty to nie tyle nauka, filozofia, czy nawet poezja, ile raczej coś w rodzaju „świeckiego mistycyzmu”, gdzie chodzi nie o żadne fakty i zależności między nimi, religijne odniesienia czy kontemplację odwiecznej prawdy, lecz tylko o wywołanie pewnych efektów umysłowych, wolnych - niestety - od zdrowego rozsądku i tak tajemniczych, że nawet zaprzeczyć im trudno, a przyznać, że się ich nie rozumie to, w pewnych kręgach, sytuacja wstydliwa? 59

\section{Wnioski}

Powyższe krytyczne analizy można by było rozwinąć, powołując się na innych przedstawicieli postracjonalizmu. Nie chodzi jednak o dokładne wykazywanie wszelkich problemów, ale o ogólną tendencję, która przebija w pracach wielu humanistów z owego kręgu intelektualnego. Widać ją zarówno w odwoływaniu się do terminów dla siebie niezrozumiałych, jak i w niejasnej metodologii postępowania. Postracjonaliści potrzebują wciąż racjonalnych znaków, lecz nie oznacza to wcale, że dzięki temu ich praca jest bardziej jasna, obiektywna czy adekwatna do rzeczywistości. To myślenie na wskroś irracjonalne, które bardzo często za nic ma fakty, zdrowy rozsądek i logiczne postępowanie. Wydaje się nawet, że jeśli na coś ważnego zwracają uwagę (np. problem wykluczenia u Kristevy ${ }^{60}$ czy kłopoty współczesnego człowieka, spowodowane rozwojem technologii i komputeryzacją szeroko pojętych relacji międzyludzkich, jak $\mathrm{u}$ Lyotarda ${ }^{61}$ lub problemy natury psychologicznej Lacana), to wcale nie jest

\footnotetext{
59 Por. A. Sokal, J. Bricmont, Modne bzdury..., dz. cyt., s. 47-48.

${ }^{60}$ Np. J. Kristeva, J. Vanier, (Bez)sens słabości, dz. cyt.

${ }^{61}$ Zob. J.-F. Lyotard, The postmodern condition, dz. cyt.
} 
to wynikiem zamierzonej refleksji intelektualnej. Często jest tak, że owi myśliciele najpierw widzą, niekiedy bardzo słusznie, pewne rodzące się i jakoś nowe zjawisko ${ }^{62}$, dopisując później swoje własne interpretacje i rozwiązania. Dlaczego tak się jednak dzieje?

Nie chcę wysuwać zbyt daleko idących wniosków, odpowiadając na powyższe pytanie, ale wydaje mi się, że odpowiedzi trzeba szukać w redukcjonizmie postracjonalnego myślenia, a jest to właściwie skrajny redukcjonizm materialistyczny. W świecie dualistycznym (materia, duch) odpowiedzi na wiele trudnych pytań dotyczących świata i człowieka wydają się dużo łatwiejsze i... dokładniejsze. Widać bowiem w takim myśleniu nie tylko zależność tego, co duchowe i materialne, ich różne wzajemnie odniesienia, ale także tajemniczość czy po prostu naturalna niepoznawalność zjawisk, zarówno materialnych czy przyrodniczych (np. praw fizyki), jak i duchowych (np. natura czy istota przyjaźni lub miłości). Myślenie otwiera się tu na meta-fizyczność, ukazując jednocześnie z pokorą braki własnych idei, dążeń czy twierdzeń. W takim ujęciu jest również miejsce dla rozwoju nauk lub idei, nawet wtedy, gdy wygłasza się aktualnie obowiązujące twierdzenia czy prawdy. Pojawia się także coś, co jest ponad mną, jakaś myśl, zasady, idee, którym powinienem się podporządkować jako człowiek rozumny.

Tymczasem w myśleniu postmodernistycznym mamy do czynienia z czymś zgoła odmiennym. Znamienne jest, że już epoka oświecenia znamionowała tendencje irracjonalne. Wypada wspomnieć tu nieco zapomnianą, aczkolwiek w pewnym sensie adekwatną do myśli dzisiejszych irracjonalistów, postać francuskiego lekarza i filozofa Juliena Offraya de La Mettriego (1709-1751). W swoich pracach ${ }^{63}$ głosił on np. tezę o materialistycznej koncepcji człowieka. Sfera duchowa człowieka w pełni wypływa z jego materii, i w związku $\mathrm{z}$ tym niewłaściwe jest mówienie o jej niezależnym istnieniu. Czynności duszy i ducha w ogóle nie istnieją. Zapewne także $z$ tych samych, materialistycznych, względów współczesny postmodernizm stara się dostrzegać i za logiczny oraz ważny uznawać, każdy przejaw ludzkiego myślenia, nawet ten, który jawi się jako niesprawdzony lub nawet niedorzeczny. Przecież wypływa on z natury, poza którą nic innego nie istnieje! $Z$ jednym jednak zastrzeżeniem. La Mettrie, żyjąc w swoich czasach i będąc zachwycony ówczesną mechaniką,

${ }^{62}$ Często nie jest to wcale zupełnie nowe doświadczenie. Dużo bardziej jest ono tylko widziane w nowym świetle lub warunkach.

${ }^{63}$ Zob. np. J. O. de La Mattrie, Dzieła filozoficzne, przeł. M. Skrzypek, Warszawa 2010; J. O. de La Mattrie, Człowiek-maszyna, przeł. S. Rudniański, Warszawa 2003. 
uznawał obiektywne prawa fizyki. Dziś, dla wielu, nawet te prawa są jedynie konstruktem psychicznym lub kulturowym zależnym od wolnego powiewu ducha. A skoro ducha właściwie nie ma, to znaczy, że jest to wyraz wolnych sił natury, które przez fakt swojej wolności są ważniejsze niż jakiekolwiek obiektywne prawa. Niestety, takie przekonania, przyjmowane powszechnie, nie wróżą nic więcej, jak tylko konflikty i rozczarowanie jednostkowe i społeczne. Przyjmowane zaś w nauce, degradują ją, czyniąc z niej coraz bardziej ideologię.

Dla tych zaś, którzy z bardzo różnych przyczyn nie są wstanie przekonać się do powyższego sposobu patrzenia na rzeczywistość, może być inne wyjście: powrót do typu racjonalności, który postmodernizm krytykuje i odrzuca, jako już nieaktualny. Zdrowy rozsądek, ogólne normy i zasady, przyjęcie faktu istnienia tajemnicy, a także pogodzenie się, że coś nie zostanie do końca wyjaśnione i poznane, gdyż rozgrywa się np. w pewnym procesie ${ }^{64}$, również może przyjść z pomocą postmodernistycznym dociekaniom.

\section{ABSTRAKT}

Postmodernistyczni humaniści często odwołują się do badań nauk szczegółowych w celu potwierdzenia swoich tez. Powstaje jednak zasadnicze pytanie: czy potrzebują oni szczegółowych nauk, aby potwierdzić swoje badania, czy też jest odwrotnie: uważają, że wszystkie badania nauk szczegółowych wypływają z tez humanistycznych lub kulturowych? Myśliciele postmodernistyczni zakładają tę drugą opcję. Wydaje się również, że owi humaniści nie są w stanie całkowicie pozbyć się racjonalnych terminów i metod, ponieważ one lepiej opisują rzeczywistość. Problem odwoływania się do nauk ścisłych i braku własnych klarownych metod podejmowany jest w prezentowanym tekście na przykładzie prac wybranych myślicieli postracjonalnych.

\section{SŁOWA KLUCZOWE}

postmodernizm, racjonalizm, irracjonalizm, filozofia współczesna

\section{Abstract}

On the Doubtful Foundations and Methodology of Postmodern Humanists. Postmodern humanists often refer to the study of particular sciences to confirm their theses. However, the general question arises: do they need these particular sciences

${ }^{64}$ Podobnych rozwiązań można doszukać się nawet u postmodernisty Baumana. Zob. np. Z. Bauman, Obcy u naszych drzwi, Warszawa 2016. 
to validate their research, or do they think that all natural research results from humanistic or cultural issues? Postmodern philosophers accept the latter option. It also seems that the postmodern humanists are not able to completely get rid of rational deadlines and methods, because it better describes reality. The problem of referring to the exact sciences and the lack of one's own clear methods is taken up in the presented text by the example of the works of selected non-rational thinkers.

\section{KEYWORDS}

postmodernism, irrationalism, rationalism, contemporary philosophy

\section{BIBLIOGRAFIA}

Althusser L., Écrits sur la psychanalyse, Paris 1993.

Amsterdamska O., Surely are you joking, Monsieur Latour, „Science, Technology \& Human Values" 15 (1990), s. 495-504.

Bauman Z., Etyka ponowoczesna, przeł. J. Bauman, J. Tokarska-Bakir, Warszawa 2012. Bauman Z., Obcy u naszych drzwi, Warszawa 2016.

Bauman Z., Płynna nowoczesność, przeł. T. Kunz, Kraków 2008.

Baudrillard J., Fatal strategies, trans. P. Beitchman, W. G. Niesłuchowski, w: Semiotext(e), ed. J. Fleming, New York 1990, s. 162-163.

Baudrillard J., The Gulf War Did Not Take Place, trans. \& intro. P. Patton, Bloomington 1995.

Baudrillard J., The Illusion of the End, trans. C. Turner, Cambridge, England 1994.

Baudrillard J., The Transparency of Evil: Essays on Extreme Phenomena, trans. J. Benedict, London 1993.

Dąbska I., Irracjonalizm a poznanie naukowe, „Kwartalnik Filozoficzny” 1938 nr 1, s. $83-118$.

Dennett D., Dźwignie wyobraźni i inne narzędzia myślenia, przeł. Ł. Kurek, Kraków 2015.

Dennett D., Odczarowanie. Religia jako zjawisko naturalne, przeł. B. Stanosz, Warszawa 2008.

Derrida J., Roudinesco É., Pochwała psychoanalizy, przeł. M. Loba, „Literatura na Świecie” $2003 \mathrm{nr}$ 3-4 (380-381), s. 273-308.

Duk A., Flew i Kistevej „poszukiwanie” Boga, „Theofos” 2019 nr 5, s. 38-53.

Duk A., Postmodernizm - od filozofii do mitu?, „Theofos” 2019 nr 5, s. 103-111.

Duk A., Zarys ateizmu postmodernistycznego Zygmunta Baumana, „Theofos” 2020 nr 6, s. 101-119.

Fukuyama F., Koniec historii, przeł. T. Bieroń, Poznań 2000. 
Fukuyama F., Wielki wstrzas: natura ludzka a odbudowa porzadku społecznego, przeł. H. Komorowska, K. Dorosz, Warszawa 2000.

Gajewski M., Funkcje i dysfunkcje myślenia irracjonalnego, „Annales UMCS” sec. I (Philosophia-Sociologia) 42, 2 (2017), s. 9-27.

Gingras Y., Un air de radicalisme: Sur quelques tendances récentes en sociologie de la science et de la technologie, „Actes de la recherche en sciences sociales” $1995 \mathrm{n}^{\circ} 108$, s. $3-17$.

Gross P. R., Levitt N., Higher Superstition: The Academic Left and Its Quarrels with Science, Baltimore 1994.

Kleszcz R., O racjonalności, Studium epistemologiczno-metodologiczne, Łódź 1998.

Kristeva J., Sìmeiōtikī: recherches pour une sémanalyse, Paris 1969.

Kristeva J., Vanier J., (Bez)sens słabości: dialog wiary z niewiara o wykluczeniu, przeł. K. i P. Wierzchosławscy, Poznań 2012.

La Mattrie J. O. de, Człowiek-maszyna, przeł. S. Rudniański, Warszawa 2003.

La Mattrie J. O. de, Dzieła filozoficzne, przeł. M. Skrzypek, Warszawa 2010.

Lacan J., Desire and the interpretation of desire in Hamlet, trans. J. Hulbert, „Yale French Studies" 1977 no. 55/56, s. 11-52.

Lacan J., Of structure as an inmixing of an otherness prerequisite to any subject whatever, trans. A. Lewańska, w: Languages of Criticism and the Sciences of Man, ed. R. Macksay, E. Donato, Baltimore 1970, s. 186-200.

Latour B., A relativistic account of Eistein's relativity, „Social Studies of Science” 1988 no. 18 , s. 3-44.

Latour B., La Science en action. Introduction à la sociologie des sciences, Paris 1989.

Lyotard J.-F., Thébaud J.-L., Just Gaming, University of Minnesota Press 1985 (Theory and History of Literature, 20).

Lyotard J.-F., The postmodern condition: a report on knowledge, transl. G. Bennington, B. Massumi; forew. F. Jameson, Minneapolis 1993; przekład polski: Kondycja ponowoczesna: raport o stanie wiedzy, przeł. M. Kowalska, J. Migasiński, Warszawa 1997.

Macmillan M., Freud oceniony. Analiza krytyczna dzieła, przeł. M. Zagrodzki, Kraków 2007.

Milner J.-C., L'ouvre claire, Paris 1995.

Popper K. R., Nędza historycyzmu, przeł. S. Amsterdamski, Warszawa 1999.

Smith D., Zygmunt Bauman: Prophet of Postmodernity, Cambridge 1999.

Sokal A., Bricmont J., Modne bzdury: o nadużywaniu pojęć z zakresu nauk ścistych przez postmodernistycznych intelektualistów, przeł. P. Amsterdamski, Warszawa 2004.

Stachowski R., Historia współczesnej myśli psychologicznej, Warszawa 2000.

Stróżewski W., Istnienie i sens, Kraków 1994. 
Szmyd J., Myślenie i zachowanie nieracjonalne, Katowice 2012.

Tatarkiewicz W., O niektórych postaciach racjonalizmu XVII i XVIII w., w: W. Tatarkiewicz, Droga do filozofii i inne rozprawy filozoficzne, Warszawa 1971, s. 109-115. Netografia:

Derrida J., Różnicość, http://bb.ph-f.org/przeklady/derrida_roznicosc.pdf (21.06.2019). https://www.kongreskobiet.pl/pl-PL/news/show/gender_studies_w_polsce (24.02.2014).

https://slw.univie.ac.at/studieren/masterstudien/gender-studies-master/(23.11.2020). Jean François Lyotard, https://plato.stanford.edu/entries/lyotard/\#JustLighPostCond (21.09.2018).

Nowak A., Przeciwko "filozofi" pogardy i nienawiści, https://wpolityce.pl/spoleczenstwo/363571-przeciwko-filozofii-pogardy-i-nienawisci (22.10.2017).

Oko D., Na czym polega wielkie kłamstwo genderyzmu? Ten wywiad po porostu trzeba przeczytać!, https://niezalezna.pl/281208-na-czym-polega-wielkie-klamstwo-genderyzmu-ten-wywiad-po-prostu-trzeba-przeczytac (24.07.2019).

Postmodernizm, http://www.ptta.pl/pef/pdf/p/postmodernizm.pdf (2010-2021).

Potracit 77-latkę na pasach?, https://wpolityce.pl/spoleczenstwo/451709-potracil-kobiete-na-pasach-co-z-tego-najsztub-uniewinniony (21.06.2019).

Racjonalizm, http://www.ptta.pl/pef/pdf/r/racjonalizm.pdf (2010-2021). 